\title{
PARATE EKSEKUSI HAK TANGGUNGAN KONTRA FIAT PENGADILAN
}

\author{
Tan, Henny Tanuwidjaja \\ Staf Pengajar Fakultas Hukum Universitas Narotama Surabaya \\ Korespondensi: dr_hennytan_notaris@yahoo.com
}

\begin{abstract}
Abstrak
Pelaksanaan Parate Eksekusi dilakukan oleh Bank sebagai alternatif penyelesaian kredit bermasalah. Artikel ini hendak mengetahui dan menganalisa peranan Parate Eksekusi Hak Tanggungan yang secara teknis sering berbenturan dengan Surat Putusan Mahkamah Agung RI No.32 10 K/Pdt/ 1984 juncto Pasal 224 H.I.R dan Pasal 26 UU Hak Tanggungan (UUHT) dengan memperhatikan ketentuan dalam pasal 14 UUHT. Telah terjadi inkonsistensi pelaksanaan Parate Eksekusi yang diharuskan dengan Fiat Pengadilan, sehingga pelaksanaan pasal 6 UUHT No. 4 Tahun 1996 menjadi terkendala. Terbitnya Surat Edaran Badan Urusan Piutang dan Lelang Negara (BUPLN) No. SE-21/PN/1998, jo SE-23/PN/ 2000/ tentang Petunjuk Pelaksanaan Pasal 6 UUHT Nomor 4 Tahun 1996 adalah sesuai dengan ketentuan pasal 6 UUHT, demikian juga dengan Grosse Akta Hak Tanggungan, jo asas lex posterior derogat legi priori yaitu pada peraturan yang sederajat, maka peraturan yang paling baru (UUHT No.4 tahun 1996), mengesampingkan peraturan yang lama (SK.MARI. No. 3210 K/Pdt/ 1984 juncto Pasal 224 H.I.R).
\end{abstract}

Kata-kata Kunci: Parate Eksekusi; Hak Tanggungan; Inkonsistensi.

\begin{abstract}
The Parate Executie enforcement is conducted by Bank as an alternative settlement for non-performing loan cases. This article will analyze the role of Parate Executie in the matter of mortgage which is technically contradictive with Mahkamah Agung RI Decision No. $3210 \mathrm{~K} / \mathrm{Pdt} / 1984$ jo Article 224 H.I.R. and Article 26 of Mortgage Law with regard to Article 14 of Mortgage Law. This article found there has been an inconsistent enforcement of Parate Executie that was undertaken with compulsory Fiat. It results a constraint implementation of Article 6 of Mortgage Law. Surat Edaran Badan Urusan Piutang dan Lelang Negara (BUPLN) No. SE-21/PN/ 1998, jo SE-23/PN/2000/ regarding implementation regulation of Article 6 of Mortgage Law No. 41996 exists to be compatible with the Article. In addition, lex posterior derogat legi priori principle concludes that the latest rule (Mortgage Law No. 4 1999) overrides the former rule (MARI. Decision No. 3210 K/Pdt/ 1984 juncto Article 224 H.I.R).
\end{abstract}

Key Words: Parate Execution; Mortgage; Inconsistency. 


\section{PENDAHULUAN}

Pelaksanaan parate eksekusi hak tanggungan yang dilakukan oleh Bank pada umumnya, dalam praktik, ternyata sering mengalami kendala terkait dengan perlu atau tidaknya Fiat Pengadilan, sejak diundangkannya Surat Putusan Mahkamah Agung RI No.3210 K/Pdt/1984, tanggal 30 Januari 1986, jo. Pasal 224 H.I.R, juga ketentuan dalam Pasal 26 UndangUndang Nomor 4 tahun 1996 tentang Hak Tanggungan atas Tanah Beserta Benda-Benda yang Berkaitan dengan Tanah (selanjutnya disebut UUHT) dan penjelasannya. Sehingga terjadi inkonsistensi pelaksanaan parate eksekusi yag diatur dalam Pasal 6 Undang-Undang Nomor 4 tahun 1996 tentang Hak Tanggungan Atas Tanah Beserta Benda-Benda Yang Berkaitan Dengan Tanah, (yang selanjutnya disebut UUHT), dilakukan oleh bank menemui permasalahan perlu tidaknya fiat pengadilan.

Diberlakukannya UUHT 9 April 1996 telah menghapus lembaga jaminan credietverband dan hipotek sebagai jaminan kredit pada bank. Mengenai hal ini tercermin dalam ketentuan Pasal 29 UUHT, yang menentukan bahwa, dengan berlakunya UUHT, ketentuan mengenai credietverband dan ketentuan mengenai hipotek sebagaimana diatur dalam Buku II KUH Perdata, sepanjang mengenai pembebanan hak tanggungan pada hak atas tanah beserta bendabenda yang berkaitan dengan tanah dinyatakan tidak berlaku lagi. Sehubungan dengan itu, maka dengan diundangkannya UUHT tersebut, hak tanggungan merupakan satu-satunya lembaga hukum jaminan yang mengatur khusus pembebanan hak atas tanah. Pengaturan oleh UUHT tersebut termasuk mencakup tata cara apabila terjadi keadaan wanprestasi (tidak membayar) oleh debitur dengan tidak melaksanakan kewajibannya.

Di dalam praktik, apabila terdapat debitur yang wanprestasi, biasanya bank akan mengirimkan surat peringatan kepada debitur agar melaksanakan kewajibannya dalam pembayaran angsuran sesuai dengan yang diperjanjikan. Peringatan tersebut biasanya diajukan paling sedikit sebanyak 3 (tiga) kali untuk memenuhi syarat keadaan wanprestasinya debitur.

Apabila telah diperingati secara patut tetapi debitur tidak juga melakukan pembayaran kewajibanya, maka bank melalui ketentuan hukum yang terdapat pada Pasal 6 dan Pasal 20 UUHT akan melakukan proses lelang terhadap jaminan debitur. Bank biasanya lebih banyak mengajukan permohonan lelang jaminan hak tanggungan kepada Balai Lelang Swasta. Selanjutnya Balai Lelang Swasta akan meneruskan permohonan tersebut kepada KPKNL (Kantor Pelayanan Kekayaan Negara dan Lelang) yang merupakan salah satu unit kerja pada Dit. Jend Kekayaan Negara Departemen Keuangan R.I.

Sesuai dengan uraian di atas maka permasalahan yang hendak dibahas di sini adalah: (1) Apakah parete eksekusi Hak Tanggungan harus dimintakan fiat 
Pengadilan? (2) Adakah kendala-kendala yuridis dan sosiolaogis dalam pelaksanaan parete eksekusi Hak Tanggungan?

\section{PEMBAHASAN}

\section{Definisi dan Pengaturan Hak Tanggungan menurut UUHT}

Menurut Pasal 1 ayat (1) UUHT, yang dimaksud dengan Hak Tanggungan adalah Hak Tanggungan atas tanah beserta benda-benda yang berkaitan dengan tanah, yang selanjutnya disebut Hak Tanggungan, adalah hak jaminan yang dibebankan pada hak atas tanah sebagaimana dimaksud dalam Undang-Undang Nomor 5 Tahun 1960 tentang Peraturan Dasar Pokok-Pokok Agraria, berikut atau tidak berikut benda-benda lain yang merupakan satu kesatuan dengan tanah itu, untuk pelunasan utang tertentu, yang memberikan kedudukan yang diutamakan kepada kreditur tertentu terhadap kreditur-kreditur lainnya.

Objek Hak Tanggungan sebagaimana yang diatur dalam Pasal 4 UUHT, terdiri atas Hak Milik, Hak Guna Bangunan, dan Hak Pakai atas Tanah Negara menurut ketentuan yang berlaku wajib didaftar dan menurut sifatnya dapat dipindah-tangankan dan dapat juga dibebani Hak Tanggungan. Salah satu ciri Hak Tanggungan sebagai lembaga jaminan atas tanah untuk pelunasan utang tertentu adalah mudah dan pasti pelaksanaan eksekusinya. Masalah jaminan berkaitan erat dengan masalah eksekusi, khususnya dalam hal eksekusi jaminan utang membuktikan peranannya, hal ni diatur dalam Pasal 20 UUHT. Setiap janji untuk melaksanakan eksekusi Hak Tanggungan dengan cara yang bertentangan dengan ketentuan pasal 20 UUHT adalah batal demi hukum ${ }^{1}$

\section{Tentang Eksekusi Hak Tanggungan Menurut UUHT}

Eksekusi Hak Tanggungan sebagaimana disebutkan di atas, yaitu eksekusi jaminan hipotik, menggunakan grosse acte hypotheek dan eksekusi berdasarkan Sertifikat Hak Tanggungan Pasal 6 dan Pasal 20 UUHT, masingmasing memiliki perbedaan dalam prosedur pelaksanaannya. Untuk eksekusi yang menggunakan titel eksekutorial berdasarkan Sertifikat Hak Tanggungan didasarkan Pasal 6 dan Pasal 20 UUHT, sedangkan dalam hal eksekusi jaminan hipotik, menggunakan grosse acte hypotheek, pelaksanaan penjualan benda jaminan tunduk dan patuh pada Hukum Acara Perdata sebagaimana yang diatur dalam Pasal 224 H.I.R. dan Pasal 258 R.Bg, sedangkan eksekusi secara di bawah tangan pelaksanaanya harus memenuhi ketentuan Pasal 20 UUHT.

Pasal 6 UUHT menentukan: “apabila debitur cidera janji, pemegang Hak

Pasal 20 Undang-Undang No. 4 Tahun 1996. ${ }^{2}$ Herowati Poesoko, Parate Executie bjek Hak Tanggungan: Inkonsistensi, Konflik Norma dan Kesesatan Penalaran dalam UUHT (LaksBang Pressindo 2007) 5. 
Tanggungan pertama mempunyai hak untuk menjual objek Hak Tanggungan atas kekuasaan sendiri melalui pelelangan umum. Istilah parate executie secara etimologis berasal dari kata "paraat" yang artinya siap di tangan, sehingga parate executie dikatakan sebagai sarana eksekusi yang siap di tangan. Di dalam doktrin/ajaran ilmu hukum, kewenangan untuk menjual atas kekuasaan sendiri" atau parate executie diberikan arti bahwa kalau debitur wanprestasi, kreditur bisa melaksanakan eksekusi objek jaminan tanpa harus meminta fiat dari ketua pengadilan, tanpa harus mengikuti aturan main dalam Hukum Acara Perdata, tidak perlu ada sita lebih dahulu, tidak perlu melibatkan juru sita dan karenanya prosedurnya lebih mudah dan biayanya lebih murah. ${ }^{2}$

Pelaksanaan parate executie yang terjadi dalam kurun waktu sejak diberlakukannya UUHT, tidak dapat dilaksanakan sebagaimana yang diharapkan oleh bank selaku kreditor karena terkendala adanya Putusan Mahkamah Agung Republik Indonesia (MARI) No. 3210 K/Pdt/ 1984, tanggal 30 Januari 1986, yang salah satu amar putusan MARI dalam suatu perkara parate eksekusi menyatakan, bahwa pelaksanaan pelelangan (maksudnya adalah parate executie) dilaksanakan sendiri oleh Kepala Kantor Lelang Negara atas perintah Bank-Kreditor dan tidak atas penetapan/fiat Ketua Pengadilan Negeri, maka menurut MARI lelang umum tersebut bertentangan dengan Pasal 224 H.I.R., sehingga pelelangan tersebut adalah tidak sah. Jadi menurut putusan tersebut pelaksanaan parate executie harus dengan fiat Ketua Pengadilan Negeri. Putusan MARI tersebut juga didukung oleh Buku II Pedoman Mahkamah Agung Republik Indonesia yang mengharuskan adanya fiat eksekusi dari Pengadilan Negeri, ${ }^{3}$ demikian juga terkendala dengan Pasal 26 UUHT.

Lebih lanjut bilamana dihubungkan dengan Penjelasan Pasal 14 ayat (2) dan (3) UUHT yang menyatakan: "Irah-irah yang dicantumkan pada sertifikat Hak Tanggungan dan dalam ketentuan pada ayat ini, dimaksudkan untuk menegaskan adanya kekuatan eksekutorial pada Sertipikat Hak Tanggungan, sehingga apabila debitor cidera janji, siap untuk dieksekusi seperti halnya suatu putusan pengadilan yang telah mem peroleh kekuatan hukum tetap, melalui tata cara dan dengan menggunakan lembaga parate executie sesuai dengan peraturan Hukum Acara Perdata."

\section{Istilah Parate Executie}

Istilah "parate executie" secara implisit telah diatur dalam UUHT. Istilah parate executie secara etimologis berasal dari kata "paraat" yang artinya siap di tangan, sehingga parate executie dikatakan sebagai sarana eksekusi yang siap di tangan ${ }^{4}$. Dari pendapat tersebut

J. Satrio, Hukum Jaminan, Hak Jaminan Kebendaan: Hak Tanggungan Buku I (Citra Aditya Bakti 2002) 219-220.

$4 \quad$ Wirjono Prodjodikoro, Hukum Perdata Tentang Hak Atas Benda (Intermasa 1986) 75. 
dapat dipahami bahwa pelaksanaan parate executie merupakan cara termudah dan sederhana bagi kreditor untuk memperoleh kembali piutangnya manakala debitor wanprestasi dibandingkan dengan eksekusi yang melalui bantuan atau campur tangan pengadilan.

Titel eksekutorial yang berbunyi "DEMI KETUHANAN YANG MAHA ESA" memang merupakan pernyataan yang mengandung kewenangan bahwa suatu dokumen atau naskah memiliki kekuatan eksekusi (pelaksanaan secara paksa) dengan bantuan alat negara. Dokumen atau naskah tersebut bisa dalam bentuk putusan pengadilan, grosse akta hipotek, sertifikat hak tanggungan, sertifikat fidusia, surat paksa yang dikeluarkan oleh PUPN maupun grosse akta pengakuan utang. Atas adanya titel eksekutorial tersebut si pemegangnya dapat mengajukan permohonan pelaksanaan secara paksa kepada pengadilan dan pengadilan akan melaksanakannya melalui prosedur eksekusi.

Putusan pengadilan yang dapat dimintakan eksekusi oleh pihak yang menang adalah putusan pengadilan yang telah berkekuatan hukum tetap yang amarnya menghukum (condemnatoir), sementara amar putusan declaratoir tidak dapat dimintakan eksekusi. Adapun putusan yang telah berkekuatan hukum tetap tersebut berupa: a. Putusan pengadilan tingkat pertama yang tak dimintakan banding atau kasasi karena telah diterima oleh kedua belah pihak.

b. Putusan pengadilan tingkat banding yang tidak dimintakan kasasi ke Mahkamah Agung.

c. Putusan pengadilan tingkat kasasi dari Mahkamah Agung ;

d. Putusan verstek dari pengadilan tingkat pertama yang tidak diverzet;

e. Putusan hasil perdamaian dari semua pihak yang berperkara ${ }^{5}$.

Eksekusi melalui pengadilan merupakan tindakan paksa yang dilakukan pengadilan dengan bantuan alat negara guna menjalankan putusan pengadilan yang telah memperoleh kekuatan hukum tetap. Selama putusan belum memperoleh kekuatan hukum tetap, upaya dan tindakan eksekusi belum berfungsi. Eksekusi baru berfungsi sebagai tindakan hukum yang sah dan memaksa terhitung sejak tanggal putusan memperoleh kekuatan hukum tetap karena pihak tergugat tidak mau menaati dan memenuhi putusan pengadilan secara sukarela ${ }^{6}$.

Sedangkan Parate eksekusi berdasarkan Pasal 6 UUHT adalah hak untuk melakukan penjualan atas kekuasaan sendiri, eksekusi ini dapat kita temukan dalam beberapa lembaga jaminan kebendaan antara lain:

Wildan Suyuthi, Sita dan Eksekusi Praktek Kepustakaan Pengadilan (Tatanusa 2004) 61.

$6 \quad$ M. Yahya Harahap, Ruang Lingkup Permasalahan Eksekusi Bidang Perdata (Sinar Grafika 2005) 25 . 
1. Gadai;

2. Hipotik ;

3. Hak Tanggungan

4. Fidusia

$\begin{array}{llll}\text { Ketentuan } & \text { Pasal } & 6 & \text { UUHT }\end{array}$ menetapkan: "Apabila debitor cidera janji, pemegang Hak Tanggungan pertama mempunyai hak untuk menjual objek Hak Tanggungan atas kekuasaan sendiri melalui pelelangan umum serta mengambil pelunasan piutangpiutangnya dari hasil penjualan tersebut". Sedangkan contoh parate eksekusi pada benda bergerak diatur dalam Pasal 15 ayat (3) Undang-Undang Nomor 42 Tahun 1999 tentang Fidusia menyebutkan: "Apabila debitur cidera janji, Penerima Fidusia mempunyai hak untuk menjual Benda yang menjadi objek Jaminan Fidusia atas kekuasaannya sendiri."

Salah satu prinsip yang diberikan undang-undang terhadap lembaga Hak Tanggungan, bahwa UUHT mensyaratkan agar hak untuk dapat melakukan penjualan atas kekuasaan sendiri itu dinyatakan secara tegas dalam perjanjiannya. Sedangkan jaminan fidusia memiliki karakteristik yang sama dengan jaminan gadai di mana para pihak tidak perlu memperjanjikan akan ada hak parate eksekusi undang-undang telah secara otomatis memberikan hak tersebut kepada si kreditur.
Pada asasnya tidak ada kredit yang tidak mengandung jaminan ${ }^{7}$ karena undang-undang telah menentukan bahwa setiap kebendaan milik debitur baik yang bergerak maupun yang tak bergerak, baik yang sudah ada maupun yang baru akan ada dikemudian hari menjadi tanggungan atas utangutangnya (Pasal 1131 KUH Perdata), namun meskipun undang-undang telah menentukan demikian bukan berarti bahwa setiap proses pelunasan dengan objek jaminan akan berjalan dengan lancar dan mudah, karena kenyataanya pihak kreditur yang menghadapi persoalan kredit macet (wanprestasi) selalu harus dihadapkan dengan segala macam perlawanan dari Debitur dalam upaya Kreditur mengambil pelunasan piutangnya.

Hak jaminan tersebut di atas adalah hak untuk pelunasan utang (vehaalsrecht), tidak mengandung hak untuk memiliki bendanya (verval beding), kreditur pemegang jaminan diberikan hak oleh undang-undang maupun hak untuk memperjanjikan kuasa untuk menjual sendiri objek jaminan tersebut ketika dikemudian hari debitur wanprestasi. ${ }^{8}$ Berdasarkan ketentuan undang-undang, kreditur pemegang jaminan kebendaan, dapat memilih beberapa alternatif pelunanasan piutangnya melalui beberapa cara antara lain:

a. Dengan cara melakukan penjualan objek jaminan atas kekuasaanya

J. Satrio, Parate Executie Sebagai Sarana Mengatasi Kredit Macet (Citra Aditya Bakti 1993) 5. Sri Soedewi Masjchoen Sofwan, Hukum Perdata: Hukum Benda (Liberty 1981) 103. 
sendiri atau yang kemudian disebut parate eksekusi bagi pemegang Hak Tanggungan pertama, berdasarkan pasal 6 Jo pasal 20 UUHT;

b. Dengan cara menggunakan titel eksekutorial melalui fiat ketua Pengadilan Negeri; berdasarkan ketentuan Pasal 224 HIR/258 Rbg tentang eksekusi grosse akta;

c. Dengan cara penjualan di bawah tangan berdasarkan kesepakatan kedua belah pihak untuk mendapatkan harga penjualan yang lebih tinggi (pasal 20 ayat 2 UUHT);

Konflik Norma Dan Kesesatan Penalaran Hukum Tentang Parate Eksekusi

Kerancuan pengertian parate eksekusi harus dengan fiat pengadilan, dilatarbelakangi oleh adanya kekeliruan para pembentuk undang-undang dan lembaga peradilan dalam memahami dua lembaga eksekusi tersebut, yaitu antara parate eksekusi dengan Fiat Pengadilan dalam grosse akte hipotek. Pendirian lembaga peradilan (Yurisprudensi) yang kemudian ditindak lanjuti oleh keluarnya Undang-Undang Nomor 4 Tahun 1996 tentang Jaminan Hak Tanggungan, telah mencampur adukkan antara pengertian parate eksekusi dan fiat pengadilan dalam grosse akte hipotek, hal ini menimbulkan kebingungan banyak kalangan terutama para pemegang jaminan (kreditur) yang sebelumnya telah memperjanjikan hak untuk melakukan penjualan objek jaminan atas kekuasaannya sendiri, apalagi dengan adanya Surat Putusan M.A. R.I. Nomor: 3201 K/Pdt/1984 yang menyatakan bahwa penjualan objek jaminan tanpa melalui pengadilan merupakan "perbuatan melawan hukum" hal tersebut telah menimbulkan ketakutan bagi para pelaksana lelang untuk menerima permohonan pelelalangan berdasarkan titel parate eksekusi dari para pemegang jaminan berdasarkan UUHT.

Dalam Kitab Undang-Undang Hukum Perdata (KUH Perdata), kita dapat menemukan klausula "hak untuk menjual atas kekuasaan sendiri" atau "beding van eigenmactig verkoop" adalah dari kalimat “... maka ia akan diberi kuasa secara mutlak untuk menjual persil yang terikat itu dimuka umum..." dalam Pasal 1178 ayat (2) KUH Perdata yang mengatur tentang lembaga jaminan hipotik. Ketentuan tersebut diberikan oleh undang-undang kepada pemegang hipotik (sekarang Hak Tanggungan pertama atas tanah) dalam bentuk sarana Parate eksecutie yang selalu siap ditangan pada waktu ia membutuhkan mengeksekusi nya, sehingga orang menyebutnya sebagai eksekusi yang selalu siap di tangan atau parate eksekusi $i^{9}$.

Ketentuan hak untuk menjual atas kekuasaan sendiri dalam jaminan Hak Tanggungan berdasarkan UndangUndang Nomor 4 tahun 1996, mengalami kesalahpahaman dari pembuat undang-undang karena telah memberikan pengertian yang tidak konsisten dan saling ber singgungan

9 J. Satrio, Parate ..., Op.Cit 23. 
dengan apa yang dimaksud dalam Pasal 224 HIR/258 Rbg tentang eksekusi grosse akta. Hal itu dapat kita lihat pada ketentuan penjelasan atas UndangUndang Hak Tanggungan Nomor 4 tahun 1996 pada bagian umum sub 9 di mana terdapat pernyataan yang berbunyi sebagai berikut: ...”dipandang perlu untuk memasukan secara khusus ketentuan tentang eksekusi Hak Tanggungan dalam undang-undang ini yaitu yang mengatur tentang lembaga parate eksekusi sebagaimana yang dimaksud dengan Pasal 224 Reglemen Indonesia Yang Diperbaharui dan Pasal 258 Reglemen Acara Perdata untuk Daerah Luar jawa dan Madura”. Jika kita telaah penjelasan undang-undang di atas menggambarkan bahwa pembentuk undang-undang diduga terdapat kekilafan dalam memahami perbedaan antara parate eksecutie dengan fiat pengadilan, yang disamakan dengan grosse acte hypotheek, sehingga pembentuk undang-undang menganggap bahwa parate eksekusi tunduk pada ketentuan Pasal 224 HIR/ $258 \mathrm{Rbg}$, padahal parate eksekusi sama sekali tidak berhubungan dengan Pasal 224HIR/258 Rbg.

Berbeda dengan apa yang disebutkan dalam penjelasan sub 9 tersebut justru dalam ketentuan Pasal dalam 20 Ayat (1) UUHT, dua lembaga eksekusi tersebut dipisahkan secara tegas. Jadi di sinilah letak inkonsistensinya lembaga peradilan, karena antara ketentuan dalam batang tubuh Undang-Undang Nomor 4 tahun 1996 dengan ketentuan penjelasannya telah saling bertentangan.

\section{Kendala-Kendala Parate Executie Hak Tanggungan}

\section{Kendala Yuridis}

1. Pelaksaan lelang melalui Pasal 6 Undang-Undang Hak Tanggungan yang tanpa melalui penetapan hakim ataupun tanpa fiat eksekusi dari pengadilan secara teoritis pasal tersebut terkendala dengan Pasal 26 Undang-Undang Hak Tanggungan, yang mengatur : Selama belum ada peraturan perundang-undangan yang mengaturnya, dengan memper hatikan ketentuan dalam pasal 14 , peraturan mengenai eksekusi hypootheek yang ada pada mulai berlakunya undang-undang Hak Tanggugan, berlaku pula pada eksekusi Hak Tanggungan.

2. Berdasarkan Putusan M.A. R.I. No. 3021 K/Pdt/1984 tertanggal 30 Januari 1984, Pengadilan tidak membenarkan penjualan objek hipotik oleh kreditur melalui lelang tanpa ada fiat dari pengadilan negeri setempat. Dalam putusan ini M.A. R.I. menyatakan berdasarkan Pasal 224 HIR pelaksanaan lelang akibat grosse akte hipotik yang memakai irah-irah seharusnya dilaksanakan atas perintah ketua pengadilan negeri.

3. Pelaksanaan eksekusi objek hak tanggungan yang masih memerlukan fiat ketua pengadilan bukanlah hanya merujuk pada putusan MA semata-mata, melainkan tersirat juga dari Pasal 26 UU Hak Tanggungan dan 
penjelasannya, dengan memperhatikan ketentuan dalam Pasal 14, bahwa grosse acte hypootheek yang berfungsi sebagai surat tanda bukti adanya hypootheek, dalam hal Hak Tanggungan adalah sertifikat Hak Tanggungan.

4. Bahwa Pihak pengadilan dalam prosesnya hanya menerima permohonan pengosongan atas tanah dan bangunan yang dibeli oleh Pihak Pembeli melalui lelang eksekusi yang dilaksanakan fiat pengadilan. Beberapa pengadilan negeri bahkan berpendapat bahwa pengosongan tanah dan bangunan yang diperoleh dari lelang eksekusi hak tanggungan harus dilakukan melalui mekanisme gugatan terlebih dahulu oleh pemohon/pemenang lelang. ${ }^{10}$

\section{Kendala Sosiologis}

Pelaksanaan lelang eksekusi Objek Hak Tanggungan berdasar-kan ketentuan Pasal 6 Undang-Undang Hak Tanggngan di KPKNL (Kantor Pelayanan Kekayaan Negara dan Lelang) diseluruh Indonesia dalam praktek berpedoman pada ketentuan Undang-Undang Hak Tanggugan dan faktor-faktor yang menjadi kendala dalam pelaksanaan lelang eksekusi berdasarkan ketentuan Pasal 6 Undang-Undang Hak Tanggungan dan penyelesaiannya, berakibat sangat merugikan Debitur khususnya yang sedang mengalami problem ekonominya yang terganggu (kurang beruntung), sehingga melakukan perlawanan terhadap eksekusi.

\section{Terjadi Inkonsistensi Parate Ekxecutie Pasal 6 UUHT}

Apabila pertimbangan MA dalam putusannya diikuti, maka fungsi dari janji untuk menjual atas kekuasaan sendiri (yang menyangkut hak tanggungan menurut Pasal 6 jo. Pasal 11 ayat (2) huruf e UUHT) menjadi kehilangan makna. Sebab, ciri pokok dari parate eksekusi berdasarkan janji untuk menjual atas kekuasaan sendiri adalah eksekusi dilakukan tanpa fiat ketua pengadilan. Kalau tetap harus ada fiat, parate eksekusi sama saja dengan eksekusi pada grosse akte hipotik dan surat utang yang mempunya titel eksekutorial. Telah terjadi pergeseran pengertian parate eksekusi menurut doktrin.

Pemerintah menjawab pertanyaan dan kerisauan kalangan perbankan melalui pengesahan UUHT. Berdasarkan peraturan ini jika debitur wanprestasi, maka objek hak tanggungan dijual melalui pelelangan umum untuk pelunasan piutang pemegang hak tanggungan dengan hak mendahului kreditur lain. Namun, menghadapi permasalahan inkonsistensi pengaturan, ada beberapa asas peraturan perundangan sebagai pedoman, yaitu: asas lex superior derogat legi inferior; asas lex specialis derogat legi generalis; Asas lex posterior derogat legi priori; asas legalitas atau

10 Rakernas Mahkamah Agung RI tanggal 2-6 Sepetember 2000 di Makassar. 
asas undang-undang tidak boleh berlaku surut (non-retroaktif).

Asas lex superior derogat legi inferior yang artinya peraturan yang lebih tinggi mengesampingkan yang rendah (asas hierarki), Dalam kerangka berfikir mengenai jenis dan hierarki peraturan perundang-undangan, pasti tidak terlepas dalam benak kita menganai teori stuffenbau Hans Kelsen. Asas lex specialis derogat legi generali adalah asas penafsiran hukum yang menyatakan bahwa hukum yang bersifat khusus (lex specialis) mengesampingkan hukum yang bersifat umum (lex generalis). Contohnya, dalam Pasal 18 UUD NRI 1945, gubernur, bupati, dan wali kota harus dipilih secara demokratis. Aturan ini bersifat umum (lex generalis). Pasal yang sama juga menghormati pemerintahan daerah yang bersifat khusus (lex specialis), sehingga keistimewaan daerah yang gubernurnya tidak dipilih secara demokratis seperti Daerah Istimewa Yogyakarta tetap dipertahankan. Asas lex Posterior Derogat Legi Priori, yaitu pada peraturan yang sederajat, peraturan yang paling baru mengesampingkan peraturan yang lama. Jadi peraturan yang telah diganti dengan peraturan yang baru, secara otomatis dengan asas ini peraturan yang lama tidak diberlakukan lagi. Biasanya dalam peraturan perundanganundangan ditegaskan secara ekspilist yang mencerminkan asas ini. Asas legalitas yaitu tiada suatu peristiwa dapat dipidana selain dari kekuatan ketentuan undang-undang pidana yang mendahuluinya." (Geen feit is strafbaar dan uit kracht van een daaran voorafgegane wetteljke strafbepaling). Asas legalitas yang mengandung tiga pengertian, yaitu:

1. Tidak ada perbuatan yang dilarang dan diancam dengan pidana kalau hal itu tidak terlebih dahulu dinyatakan dalam suatu aturan undang-undang;

2. Untuk menentukan adanya perbuatan pidana tidak boleh digunakan analogi (qiyas);

3. Aturan-aturan hukum pidana tidak berlaku surut. ${ }^{11}$

Berdasarkan asas lex posterior derogat legi priori, yaitu pada peraturan yang sederajat, peraturan yang paling baru menyam pingka $n$ peraturan yang lama. Jadi peraturan yang telah diganti dengan peraturan yang baru, secara otomatis dengan asas ini peraturan yang lama tidak berlaku lagi. Biasanya dalam peraturan perundangan-undangan ditegaskan secara eksplisit yang mencerminkan asas ini. Dengan demikian, Putusan Mahkamah Agung Republik Indonesia (MARI) No. 3210 K/ Pdt/1984, tanggal 30 Januari 1986 jo. Pasal 224 H.I.R, secara hukum telah digantikan oleh Undang-Undang yang lebih baru, yaitu UUHT. Oleh karenanya berdasarkan UUHT tersebut, Parate Eksekusi dapat dilakukan sendiri oleh kreditur secara langsung (Pasal 6 UUHT). 


\section{PENUTUP}

\section{Kesimpulan}

Parate eksekusi Hak Tanggungan dapat dilakukan langsung tanpa fiat Pengadilan berdasarkan Surat Edaran Badan Urusan Piutang dan Lelang Negara (BUPLN) No. SE-21/PN/1998 juncto SE-23/PN/2000 tentang Petunjuk Pelaksanaan Pasal 6 UndangUndang Nomor 4 Tahun 1996 tentang Hak Tanggungan telah sesuai dengan ketentuan Pasal 6 UUHT yang menentukan bahwa kreditur dapat melakukan eksekusi Hak Tanggungan dengan kewenangan sendiri, demikian juga dengan Grosse Akta Hak tanggungan dilakukan dengan lelang tanpa fiat pengadilan.

Kendala-kendala dalam eksekusi Hak Tanggungan meliputi kendala yuridis dan kendala sosiologis. Kendala yuridis utamanya adalah Putusan MA No. 3021/K/Pdt/1984 (30 Januari 1984) yang menyatakan bahwa parate eksekusi yang dilakukan tidak dengan meminta persetujuan ketua pengadilan negeri, meskipun didasarkan Pasal 1178 ayat (2) KUH Perdata, adalah perbuatan melawan hukum dan lelang yang dilakukan adalah batal demi hukum. Hal ini berpotensi menimbulkan ketidakpastian hukum. Sementara kendala sosiologisnya adalah perlawanan melalui gugatan pengadilan, yang dilakukan oleh debitur ketika mengetahui bahwa bank akan melakukan upaya eksekusi atas tanah dan atau bangunan yang menjadi jaminan kredit dan kesulitan bank mencari pembeli lelang atas tanah dan bangunan yang menjadi objek lelang eksekusi tersebut.

\section{DAFTAR BACAAN}

Harahap, M. Yahya, Ruang Lingkup Permasalahan Eksekusi Bidang Perdata (Sinar Grafika 2005).

Poesoko, Herowati, Parate Executie Objek Hak Tanggungan: Inkonsistensi, Konflik Norma dan Kesesatan Penalaran dalam UUHT (LaksBang Pressindo 2007).

Prodjodikoro, Wirjono, Hukum Perdata Tentang Hak Atas Benda (Intermasa 1986).

Satrio, J., Parate Executie Sebagai Sarana Mengatasi Kredit Macet (Citra Aditya Bakti 1993). , Hukum Jaminan, Hak Jaminan Kebendaan: Hak Tanggungan Buku I (Citra Aditya Bakti 2002).

Sofwan, Sri Soedewi Masjchoen, Hukum Perdata: Hukum Benda (Liberty 1981).

Suyuthi, Wildan, Sita dan Eksekusi Praktek Kepustakaan Pengadilan (Tatanusa 2004). 